Pesq. Vet. Bras. 30(5):406-410, maio 2010

\title{
Perfil de sensibilidade antimicrobiana e detecção do gene ISS pela reação em cadeia da polimerase na tipificação de Escherichia coli patogênica em codornas de corte sob inspeção sanitária1
}

\author{
Dayse Lima da Costa Abreu²*, Robson Maia Franco ${ }^{3}$, Elmiro Rosendo do \\ Nascimento ${ }^{4}$, Virginia Léo de Almeida Pereira ${ }^{4}$, Fernanda Martinez Xavier \\ Alves $^{2}$ e Juliana Ferreira de Almeida ${ }^{2}$
}

\begin{abstract}
Abreu D.L.C., Franco R.M., Nascimento E.R., Pereira V.L.A., Alves F.M.X. \& Almeida J.F. 2010. [Profile of antimicrobial resistance and detection of iss gene by the polymerase chain reaction in the typification of pathogenic Escherichia coli in meat type quails under sanitary inspection.] Perfil de sensibilidade antimicrobiana e detecção do gene iss pela reação em cadeia da polimerase na tipificação de Escherichia coli patogênica em codornas de corte sob inspeção sanitária. Pesquisa Veterinária Brasileira 30(5):406-410. Departamento de Tecnologia de Alimentos, Universidade Federal Fluminense, Niterói, RJ 24320-340, Brazil. E-mail: dayseabreu@predialnet.com.br

The pathogenicity of Escherichia coli strains is partially related to the expression of virulence factors genes, present in genetic elements called plasmids. APEC strains responsible for diseases in birds may present the iss gene which increases the resistance of $E$. coli strains to the lityc effect of the host's serum, besides resistance to several antimicrobials. This study was conduced in order to detect $E$. coli in tracheae of meat-type quails and to evaluate, by the presence of the iss gene and the profile of antimicrobial susceptibility, the pathogenic potential of the isolated samples for birds and humans. One hundred and eighty tracheae of quails were collected for detection of $E$. coli, antimicrobial sensitivity tests, and for polymerase chain reaction (PCR), for detection of iss gene. From the examined quails, $8.9 \%(16 / 180)$ were positive for $E$. coli, from which 20 strains of this bacterium were obtained. Most of them were resistant to Tetracycline (16/20), followed by Ceftadizime (13/20) and Nalidixic-acid (12/20) and only one isolate was resistant to Amoxicillin. The detection of iss gene occurred in 55\% (11/20) of the isolates, indicating that these strains had the potential to be pathogenic not only for quails, but also for other kinds of birds, other animals and even human beings that would be in contact with these $E$. coli isolates.
\end{abstract}

INDEX TERMS: Coturnix, Escherichia coli, gene iss.

RESUMO.- A patogenicidade das cepas de Escherichia coli está relacionada à expressão de fatores de virulência encontrados em elementos genéticos denominados plasmídios. O patotipo APEC, responsável por diferentes

\footnotetext{
${ }^{1}$ Recebido em 25 de março de 2009.

Aceito para publicação em 23 de dezembro de 2009.

2 Pós-Graduanda em Medicina Veterinária, Área de concentração em Higiene e Processamento Tecnológico de Produtos de Origem Animal, Departamento de Tecnologia de Alimentos (MTA), Universidade Federal Fluminense (UFF), Rua Vital Brasil Filho 64, Santa Rosa, Niterói, RJ 24320 340, Brasil. *Autor para correspondência: dayseabreu@predialnet.com.br

${ }^{3}$ Departamento de Tecnologia de Alimentos, UFF, Niterói, RJ.

${ }^{4}$ Departamento de Saúde Coletiva Veterinária e Saúde Pública, UFF, Niterói, RJ.
}

tipos de doenças em aves, pode apresentar o gene iss que aumenta a resistência das cepas de $E$. coli aos efeitos líticos do soro, além da resistência a diversos antimicrobianos. Este estudo foi conduzido para detectar E. coli em traquéias de codornas destinadas ao abate e avaliar, pela presença do gene iss e o perfil de susceptibilidade antimicrobiana, o potencial patogênico para aves e humanos dos isolados obtidos. Foram coletadas 180 traquéias de codornas para detecção de E. coli, determinação do perfil de resistência a agentes antimicrobianos e posterior detecção, por reação em cadeia da polimerase (PCR), do gene iss. Das traquéias analisadas, 8,9 \% (16/180) foram positivas para $E$. coli, sendo obtidos 20 isolados deste agente. A maioria dos isolados foi resistente à Tetraciclina 
(16/20), seguida pela Ceftazidima (13/20) e Ácido Nalidíxico (12/20), sendo apenas um resistente à Amoxicilina. A detecção do gene iss ocorreu em $55 \%$ (11/20) dos isolados. A presença do gene iss e a resistência a múltiplos antimicrobianos dos isolados obtidos neste estudo pode indicar um possível potencial patogênico das cepas de E. coli tanto para codornas quanto para outros tipos de aves e animais e mesmo para o ser humano que fique em contato com as mesmas.

TERMOS DE INDEXAÇÃO: Cotumix, Escherichia coli, gene iss.

\section{INTRODUÇÃO}

Nas aves, doenças causadas por Escherichia coli têm caráter extraintestinal, com a infecção geralmente se iniciando no epitélio traqueal (Vidotto et al. 1997). Agentes responsáveis por doenças respiratórias comumente causam aerossaculites, que são responsáveis pela elevação da taxa de condenação de carcaças. Além disso, a presença de aerossaculite exerce um impacto negativo no peso final das aves destinadas ao abate, causando desuniformidade dos lotes. Essa desuniformidade contribui para o aumento das falhas durante o processamento, principalmente durante a evisceração, elevando o risco de contaminação das carcaças com patógenos do trato intestinal (Russel 2003).

Cepas de E. coli patogênicas para aves (Avian Pathogenic E. coli, APEC) podem apresentar aumento de resistência aos efeitos líticos do soro (increased serum survival - iss), sendo esta característica determinada por gene plasmidial (Silveira et al. 1994, Ewers et al. 2007). Embora Silveira et al. (1994) e Fantinatti et al. (1994) tenham demonstrado que a presença per se do plasmídio, contendo o gene iss, não é suficiente para determinar a capacidade patogênica de uma cepa de E.coli, este gene pode ser considerado como marcador de virulência, pois, comparado a outros fatores de virulência, o gene iss é citado como o mais prevalente em cepas oriundas de aves doentes (Gibbs et al. 2003, Ozawa et al 2008, Rocha et al. 2008). Comparando a presença do gene iss entre aves com manifestações relacionadas à colibacilose e aves saudáveis, o gene iss é mais prevalente nas aves doentes (McPeake et al. 2005, Nolan et al. 2002). Esse mesmo gene pode ser encontrado com freqüência em cepas extraintestinais (Extraintestinal Pathogenic E. coli, ExPEC) isoladas de fontes humanas (Fernandez-Bero et al. 1990, Ewers et al. 2007) e codifica a produção da proteína Iss, que exerce seu efeito anticomplemento inativando o complexo de ataque à membrana bacteriana (Waters \& Crosa 1991). Cepas do patotipo ExPEC também foram isoladas de alimentos crus, carne bovina e carne de aves, indicando que essas cepas representam uma nova classe de patógenos transmissíveis por alimentos (Smith et al. 2007).

O gene iss foi localizado em vários plasmídios conjugativos de alto peso molecular capazes de carrear, simultaneamente, fatores de virulência e de resistência a antimicrobianos (Doetkott et al. 1996). Através da conjugação, bactérias comensais, inclusive de espécies diferentes, podem se tornar mais patogênicas e resistentes (Gomes et al. 1991, Skyberg et al. 2003).

Johnson et al. (2002) localizaram, em uma cepa de $E$. coli do patotipo $A P E C$, um plasmídio $\mathrm{R}$ de 101 kilobases (kb) que codificava, além do gene iss, a resistência a oito grupos de agentes antimicrobianos (tetraciclina, sulfonamidas, aminoglicosídeos, trimetoprim e agentes beta-lactâmicos), metais pesados, como o nitrato de prata, e a dois desinfetantes (composto quaternário de amônia e cloreto de benzalcônio). Tivendale et al. (2004) descreveram a presença do gene iss em um plasmídio denominado de pMV01 (160kb), necessário para a colonização do trato respiratório por possuir o gene tsh, envolvido na ligação de E. coli ao trato respiratório. O gene iss também foi descrito por Johnson et al. (2006) em um plasmídio denominado de ColV, que possuía, além do gene iss, mais 12 fatores de virulência, freqüentemente encontrados em E. coli do patotipo APEC. Embora a associação entre a presença do gene iss e a resistência a antimicrobianos não tenha sido estabelecida, Yang et al. (2004) relataram que em 71 isolados provenientes de galinhas, que apresentavam resistência à múltiplos antimicrobianos, a maioria (97\%) portava o gene iss, quando comparados a outros fatores de virulência.

Fatores de virulência podem ser trocados entre bactérias presentes na microbiota das aves e na de humanos (Doetkott et al. 1996, Stehling et al. 2003). Johnson et al. (2007), ao caracterizarem cepas de $E$. coli aviárias e humanas, quanto à resistência antimicrobiana, sugeriram que muitos isolados humanos resistentes poderiam ter se originado de cepas aviárias por conjugação. Roy et al. (2006) isolaram cepas de E. coli resistentes a vários antimicrobianos em codornas com colibacilose.

Cepas de E. coli podem ser isoladas facilmente da região da faringe e do trato respiratório de aves sadias (Ferreira \& Knöbil 2000) e ainda aumentarem consideravelmente durante o processamento (Berrang et al. 2003, Buhr et al. 2005).

Diante dos dados expostos, este trabalho tem como objetivo detectar E. coli em traquéias de codornas destinadas ao abate e avaliar, pela presença do gene iss e perfil de susceptibilidade antimicrobiana dos isolados obtidos, o potencial patogênico para as aves e risco à saúde dos consumidores.

\section{MATERIAL E MÉTODOS}

Foram utilizadas 180 codornas (Coturnix coturnix coturnix), selecionadas de forma randômica. Foram retiradas 120 codornas antes da entrada na linha de processamento, eutanasiadas e necropsiadas para avaliação das lesões macroscópicas. As outras 60 foram selecionadas depois do exame post mortem, após condenação pela observação de lesões nas carcaças. Fragmentos de traquéias foram coletados e acondicionados individualmente em tubos contendo salina fosfatada tamponada (Phosphated Buffered Saline - PBS) com $50 \%$ de glicerol, e mantidas sob congelamento até o momento das análises.

As amostras de traquéias, acondicionadas em PBS glicerinado, foram descongeladas e maceradas individualmente. Alíquotas de cada macerado foram inoculadas, com o auxílio de alça de platina, em caldo tripticase e incubados a $37^{\circ} \mathrm{C}$ por 24 horas. O isolamento de Escherichia coli, a partir do enriquecimento em caldo tripticase, foi realizado em ágar 
MacConkey e em ágar sangue e incubados a $37^{\circ} \mathrm{C}$ por 24 horas. Três colônias de cada meio, com características compatíveis com E.coli, foram transferidas para o meio Triple Sugar Iron (TSI) e para os meios Sulfeto Indol Motilidade (SIM), Citrato, Motilidade Indol Lisina (MILi) e meio de Rugai e Araújo modificado para caracterização bioquímica final (Toledo et al. 1982a,b, Quinn et al. 1998).

Os testes de resistência dos isolados caracterizados como sendo $E$. coli a diferentes antimicrobianos foram realizados através do método de disco difusão ${ }^{4}$ de acordo com normas do Clinical and Laboratory Standards Institute (CLSI 2003), utilizando os antimicrobianos amoxicilina, ampicilina, ceftazidima, cefoxitina, ciprofloxacina, enrofloxacina, gentamicina, ácido nalidíxico, polimixina $B$, cotrimoxazol e tetraciclina.

Para a reação em cadeia da polimerase (PCR), DNA genômico e plasmidial foram extraídos pelo método térmico, segundo utilizado por Gonçalves (2005). Na amplificação de DNA foi feita uma solução contendo $5 \mu \mathrm{L}$ de DNA, acrescida em uma mistura contendo: $21 \mu \mathrm{L}$ de água para PCR ${ }^{5}$ livre de DNAse e RNAse, $10 \mu \mathrm{L}$ de tampão de PCR (10x), $5 \mu \mathrm{L}$ de $\mathrm{MgCl}_{2}(25 \mathrm{mM}), 5 \mu \mathrm{L}$ de mistura de dNTPs (10 mM), 100pmol de cada "primer" (5'- GTG GCG AAA ACT AGT AAA ACA GC 3' e 5' - CGC CTC GGG GTG GAT AA 3') (Prodimol, MG) e 2U de Taq DNA polimerase, num volume final de $50 \mu \mathrm{L}$ e submetida, em um termociclador ${ }^{6}$, a uma temperatura de $94^{\circ} \mathrm{C}$ por cinco minutos e 30 ciclos de amplificação, que compreendiam a desnaturação a $94^{\circ} \mathrm{C}$ por um minuto, pareamento a $61^{\circ} \mathrm{C}$ por um minuto e extensão a $720 \mathrm{C}$ por dois minutos. Após esses ciclos seguiu-se uma etapa final de $72^{\circ} \mathrm{C}$ por dois minutos e a refrigeração das amostras a uma temperatura de $4^{\circ} \mathrm{C}$.

Duas amostras positivas para a presença do gene iss, cedidas pelo Laboratório de Epidemiologia Molecular da Universidade Federal Fluminense, foram utilizadas como controle positivo da prova. Como marcador de peso molecular foi utilizado o Ladder 100 $\mathrm{pb}^{7}$.

Os resultados foram obtidos após a corrida dos amplificados por eletroforese em gel de agarose ${ }^{8}$ a $1,5 \%$, em tampão TBE $0,5 \mathrm{X}$, a $94 \mathrm{~V}$, durante aproximadamente 40 minutos, corados com brometo de etídio numa concentração de $3 \mu \mathrm{g} / \mathrm{mL}$, sob agitação suave durante 15 minutos e visualização sob luz ultravioleta em transiluminador ${ }^{9}$.

\section{RESULTADOS E DISCUSSÃO}

Nenhuma das codornas apresentou sinais clínicos compatíveis com doença respiratória na ocasião dos exames ante-mortem, nem lesões macroscópicas no sistema respiratório à necropsia. A ausência destes sinais clínicos e lesões macroscópicas, no entanto, não exclui a presença de E. coli no trato respiratório das aves, pois este agente pode ser facilmente isolado da região da faringe e do trato respiratório de aves sadias (Ferreira \& Knöbil 2000).

\footnotetext{
${ }^{4}$ Sensiobiodisc $\circledast$ CECON, Rua Maranguape 84, Vila Sonia, São Paulo, SP

${ }^{5}$ Ludwig Biotec, Ludwig Biotecnologia, Rua Vasco da Gama 1254, São Caetano, Alvorada, RS.

6 Controller-PTC-100®, Programmable Thermal, Bio-Rad Laboratories Inc., Alfred Nobel Drive 1000, Hercules, California, USA.

${ }^{7}$ Prodimol, Prodimol Produtos Biológicos, Av. Irai 438, Moema, São Paulo, SP.

${ }^{8}$ LGC Biotecnologia, Rua Barão do Rego barros 542, São Paulo, SP.

${ }^{9}$ EB- 20E Ultra Lum, Inc., N. Claremont Boulevard 1480, Claremont, California.
}

Das 180 codornas utilizadas neste estudo foram obtidos 20 isolados de $E$. coli, mas apenas das 60 codornas condenadas durante o processamento $(26,6 \%-16 / 60)$. As condenações foram causadas por alterações caracterizadas por artrite, celulite, dermatite, salpingite, ascite, caquexia, contusões, fraturas, síndromes hemorrágicas e contaminação das carcaças com fezes, por rompimento do trato intestinal. Admite-se que as aves que foram condenadas, e portavam o agente na traquéia, passaram pela linha de abate e 0 processamento possibilitou o aparecimento de Escherichia coli. Berrang et al. (2003) e Buhr et al. (2005) detectaram um aumento na contagem de $E$. coli em traquéias de aves após a escaldagem e relataram que esta ocorrência foi possível pela aspiração de um significante volume de água dos tanques de escaldagem por ação muscular da carcaça.

As cepas de E. coli isoladas das traquéias de codornas apresentaram múltipla sensibilidade antimicrobiana, semelhante ao que foi descrito em cepas isoladas de casos de colibacilose em codornas por Roy et al. (2006). A maior resistência foi observada para a Tetraciclina (16/20), seguida pela Ceftazidima (13/20) e Ácido Nalidíxico (12/20). Apenas um isolado foi resistente a Amoxicilina e nenhum apresentou resistência aos outros antimicrobianos utilizados. Assim como os fatores de virulência, a resistência antimicrobiana pode ser adquirida por conjugação com bactérias da microbiota normal dos indivíduos (Doetkott et al. 1996, Johnson et al. 2007, Stehling et al. 2003) o que contribui para a seleção de bactérias resistentes, trazendo riscos à saúde dos consumidores de produtos avícolas.

O gene iss foi detectado por PCR em 11 dos 20 isolados de E. coli das codornas estudadas (Fig.1 e 2). A colibacilose nas aves ocorre com freqüência em caráter sistêmico ou extraintestinal (Vidotto et al. 1997), devido à resistência aos efeitos líticos do soro, conferida principalmente pela presença do gene iss. As evidências obtidas por Ozawa et al. (2008), Rocha et al. (2008) e Gibbs et al. (2003), sugerem, no entanto, a necessidade de outros fatores de virulência para caracterizar a patogenicidade dos isolados de $E$.

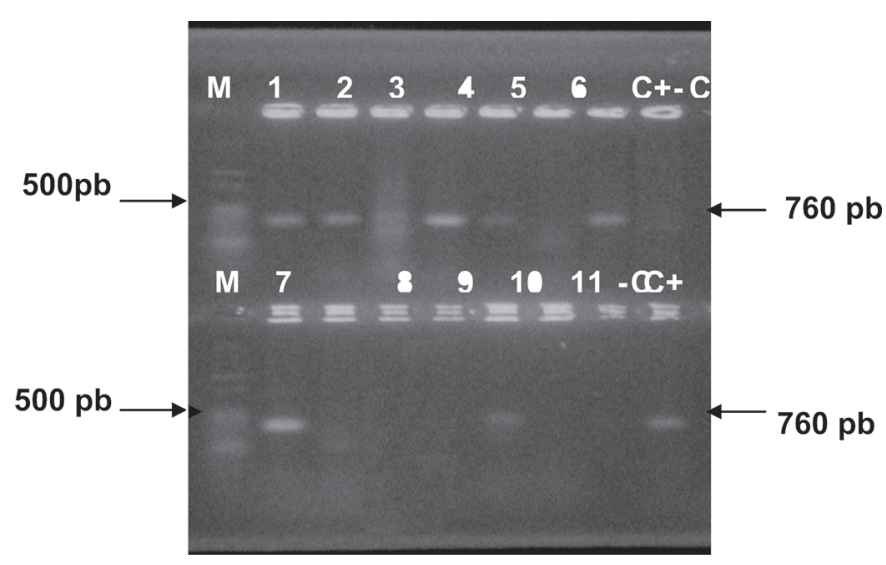

Fig.1. Resultado da PCR para o gene iss em cepas de Escherichia coli isoladas de traquéias de codornas condenadas ao abate. $\mathrm{C}+$ controle positivo, C- controle negativo. Cepas positivas: 1 , 2, 3, 4, 5, 7 e 10. Cepas negativas: 6, 8, 9 e 11. 


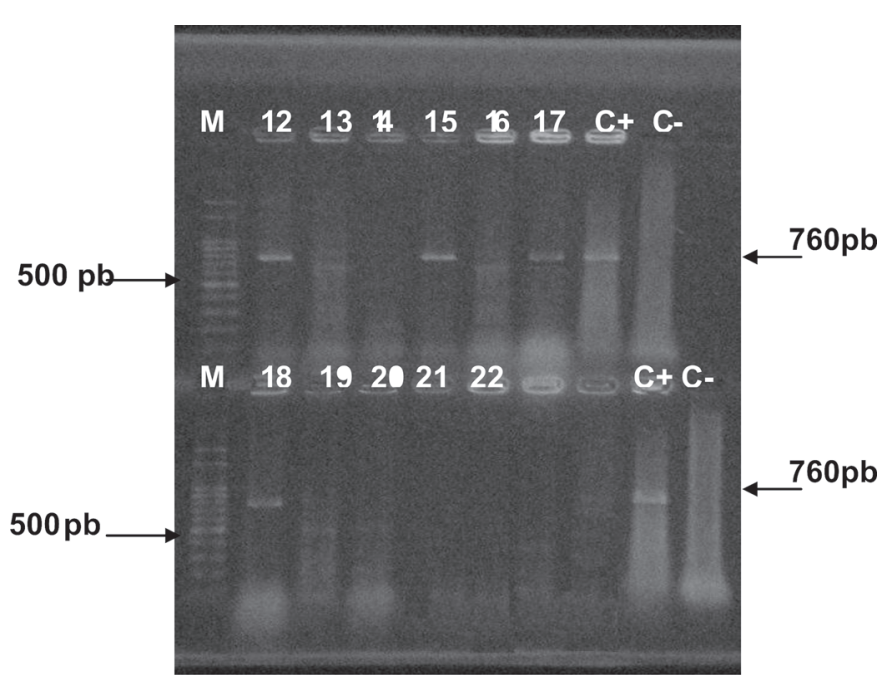

Fig.2. Resultado da PCR para o gene iss em cepas de Escherichia coli isoladas de traquéias de codornas condenadas ao abate. C+ controle positivo, C- controle negativo. Cepas positivas: 12 , 15 e 17. Cepas negativas: 13, 14, 16, 19, 21 e 22.

coli. A presença do gene iss nesses isolados indica a existência de plasmídios conjugativos de grande peso molecular, possuidores, muitas vezes, de genes de virulência adicionais, assim como genes responsáveis pela resistência aos antimicrobianos (Johnson et al. 2002, Tivendale et al. 2004, Johnson et al. 2006), conferindo maior possibilidade às cepas bacterianas que os possuam, de transmitirem esses fatores às cepas da microbiota de outros indivíduos, inclusive humanos. A associação entre a presença do gene iss e a resistência a antimicrobianos não foi estabelecida de forma consistente, mas há relatos de que isolados apresentando resistência à múltiplos antimicrobianos frequentemente apresentam o gene iss (Yang et al. 2004).

Sendo assim, a detecção do gene iss em cepas de $E$. coli nos faz crer que medidas sanitárias devam ser tomadas, desde a produção até o processamento, de forma a resguardar a saúde dos plantéis e a qualidade sanitária das carcaças de codornas destinadas ao consumo humano.

\section{CONCLUSÕES}

Bactérias da espécie Escherichia coli, muitas delas portadoras do gene iss, estão presentes em traquéias de codornas abatidas sob Inspeção Sanitária.

A presença do gene iss e a resistência a múltiplos antimicrobianos dos isolados obtidos neste estudo pode indicar um possível potencial patogênico das cepas de E. coli tanto para codornas quanto para outros tipos de aves e animais e mesmo para o ser humano, uma vez que as codornas usadas neste estudo são usadas para consumo.

Agradecimentos.- Ao Conselho Nacional de Desenvolvimento Científico e Tecnológico (CNPq) e à Fundação de Amparo à Pesquisa do Estado do Rio de Janeiro (FAPERJ).

\section{REFERÊNCIAS}

Berrang M.E., Meinersmann R.J., Buhr R.J., Reimer N.A., Philips R.W. \& Harrison M.A. 2003. Presence of Campylobacter in the respiratory tract of broiler carcasses before and after commercial scaldin. Poult. Sci. 82(12):1995-1999.

Buhr R.J., Berrang M.E., Cason J.A. \& Bourassa D.V. 2005. Recovery of bacteria from broiler carcass respiratory tracts before and after immersion scalding. Poult. Sci. 84(11):1769-1773.

CLSI 2003. Performance Standards for Antimicrobial Disk Susceptibility Tests: Approved standard. $8^{\text {th }}$ ed. Clinical and Laboratory Standards Institute. Disponível em: http://www.anvisa.gov.br/ servicosaude/ manuais /clsi.asp. Acesso em 22 jan. 2009.

Doetkott D.M., Nolan L.K., Giddings C.W. \& Berryhill D.L. 1996. Large plasmids of avian Escherichia coli isolates. Avian Dis. 40(4):927-930.

Ewers C., Wilking H., Kiessling S., Alt K., Antão E.M., Laturnus C., Diehl I., Glodde S., Homeier T., Bohnke U., Steinruk H., Philipp H.C. \& Wieler L.H. 2007. Avian pathogenic, uropathogenic, and newborn meningitis-causing Escherichia coli: How closely related are they? Int. J. Med. Microbiol. 297(3):163-176.

Fantinatti F., Silveira W.D. \& de Castro A.F.P. 1994. Characteristics associated with pathogenicity of avian septicaemic Escherichia coli strains. Vet. Mic. 41(1):75-86.

Fernandez-Bero M.E., Kissel V., Lion H. \& Cabello F.C. 1990. Virulencerelated genes in ColV plasmids of Escherichia coli isolated from human blood and intestines. J. Clin. Microbiol. 28(4):742-746.

Ferreira A.J.P. \& Knöbil T. 2000. Colibacilose aviária, p.197-207. In: Berchieri Jr A. \& Macari M. (Eds), Doenças das Aves. FACTA, Campinas, SP

Gibbs P.S., Maurer J.J., Nolan L.K. \& Wooley E. 2003. Prediction of chicken embryo lethality with the avian Escherichia coli traits complement resistance, colicin $\mathrm{V}$ production, and presence of increased serum survival gene cluster (iss). Avian Dis. 47(2):370-379.

Gomes T.A.T., Toledo M.R.F. \& Trabulsi L.R. 1991. Genética bacteriana, p.25-35. In: Trabulsi L.R., Microbiologia. Livraria Editora Atheneu, Rio de Janeiro, RJ.

Gonçalves P.M.R. 2005. Escherichia coli com detecção do gene iss por PCR, micoplasmas e salmonelas na qualidade sanitária de frangos de corte ao abate. Tese de Doutorado em Medicina Veterinária, Curso de Pós-Graduação em Higiene Veterinária e Processamento Tecnológico de Produtos de Origem Animal, Universidade Federal Fluminense, Niterói, RJ. 84p.

Johnson T.J., Giddings C.W., Horne S.M., Gibbs P.S., Wooley R.E., Skyberg J., Olah P., Kercher R., Sherwood J.S., Foley S.L. \& Nolan L.K. 2002. Location of increased serum survival gene and selected virulence traits on a conjugative $\mathrm{R}$ plasmid in an avian Escherichia coli isolate. Avian Dis. 46(2):342-352.

Johnson T.J., Siek K.E., Johnson S.J. \& Nolan L.K. 2006. DNA sequence of a ColV plasmid and prevalence of selected plasmidencoded virulence genes among avian Escherichia coli strains. J. Bacteriol.188(2):745-758.

Johnson J.R., Sannes M.R., Croy C., Johnston B., Clabots C., Kuskowski M.A., Bemder J., Smith K.E., Winokur P.L. \& Belongia E.A. 2007. Antimicrobial drug-resistent Escherichia colifrom humans and poultry products, Minnesota and Wisconsin, 2002-2004. Emerg. Infect. Dis. 13(6):838-845.

McPeak S.J.W., Smyth J.A. \& Ball H.H. 2005. Characterisation of avian pathogenic Escherichia coli (APEC) associated with colisepticaemia compared to faecal isolates from health birds. Vet. Microbiol. 110(3):245-253.

Nolan L.K., Giddings C.W., Horne S.M., Doetkott C., Gibbs P.S., Wooley R.E. \& Foley S.L. 2002. Complement resistance, as determined by viable count and flow cytometric methods, and its association with the presence of iss and the virulence of avian Escherichia coli. Avian Dis. 46(2):386-392.

Ozawa M., Harada K., Kojima A., Asai T. \& Sameshima T. 2008. Antimicrobial susceptibilities, serogroups, and molecular characterization of avian pathogenic Escherichia coli isolates in Japan. 2008. Avian Dis. 52(3):392-397. 
Quinn P.S., Carter M.E., Marvey B. \& Carter G.R. 1998. Clinical Veterinary Microbiology. Wolfe Publishing, London, p.648.

Rocha A.C.G.P., Rocha S.L.S., Lima-Rosa C.A.V., Souza G.F., Moraes H.L.S., Salle F.O., Moraes L.B. \& Salle C.T.P. 2008. Genes associated with pathogenicity of avian Escherichia coli (APEC) isolated from respiratory cases of poultry. Pesq. Vet. Bras. 28(3):183-186.

Roy P., Purushothaman V., Koteeswaran A. \& Dhillon A.S. 2006. Isolation, characterization, and antimicrobial drug resistence pattern of Escherichia coli isolated from japanese quail and their environment. J. Appl. Poult. Res. 15(3):442-446.

Russel S.M. 2003. The effect of airsacculitis on bird weights, uniformity, fecal contamination, processing errors, and populations of Campylobacter spp and Escherichia coli. Poult. Sci. 82(8):1326-1331.

Silveira W.D., Fantinatti F. \& de Castro A.F. P. 1994. Transposon mutagenesis and membrane protein studies in an avian colisepticaemic Escherichia coli strain. Rev. Bras. Gen. 17(1):914.

Skyberg J.A., Horne S.M., Giddings C.W., Wooley R.E., Gibbs P.S. \& Nolan L. 2003. Characterizing avian Escherichia coli isolates with multiplex polymerase chain reaction. Avian Dis. 47(4):14411447.

Smith J.L., Fratamico P.M. \& Gunther N.W. 2007. Extraintestinal pathogenic Escherichia coli. Foodborne Pathog. Dis. 4(2):134163.
Stehling E.G., Tomomasa Y., Brocchi M. \& Silveira W.D. 2003. Characterization of a plasmid-encoded adhesin of avian pathogenic Escherichia coli (APEC) strain isolated from a case of Swollen Head Syndrome (SHS). Vet. Microbiol. 95(2):111-120.

Tivendale K.A., Allen J.L., Ginns C.A., Crabb B.S. \& Browning G.F. 2004. Association of iss and iucA, but not $t s h$, with plasmid-mediated virulence of avian pathogenic Escherichia coli. Infect. Immun. 72(11): 6554-6560.

Toledo M.R.F., Fontes C.F. \& Trabulsi L.R. 1982a. MILi, um meio para a realização dos testes de motilidade, indol e lisina descarboxilase. Revta Microbiol. 13(3):230-235.

Toledo M.R.F., Fontes C.F. \& Trabulsi L.R. 1982b. EPM, modificação do meio de Rugai e Araújo para a realização simultânea dos testes de produção de gás a partir da glicose, $\mathrm{H}_{2} \mathrm{~S}$, urease e triptofano desaminase. Revta Microbiol. 13(4):309-315.

Vidotto M.C., Navarro H.R. \& Gaziri L.C.J. 1997. Adherence pili of pathogenic strains of avian Escherichia coli. Vet. Microbiol. 59(1):7987.

Waters V.L. \& Crosa J.H. 1991. Colicin V virulence plasmids. Microbiol. Mol. Biol. Rev. 55(3):437-450.

Yang H., Chen S., White D.G., Zhao S., McDermott P., Walker R. \& Meng J. 2004. Characterization of multiple antimicrobial resistant Escherichia coli isolates from diseased chickens and swine in China. J. Clin. Microbiol. 42(8):3483-3489. 